Review

\title{
Antibiotic Use and Resistance in Long Term Care Facilities
}

\author{
Laura W. van Buul MSc ${ }^{\mathrm{a}, \mathrm{b}}$, Jenny T. van der Steen $\mathrm{PhD}^{\mathrm{a}, \mathrm{b}, *}$, Ruth B. Veenhuizen MD, PhD ${ }^{\mathrm{a}, \mathrm{b}}$, \\ Wilco P. Achterberg MD, PhD ${ }^{\mathrm{c}}$, François G. Schellevis MD, PhD ${ }^{\mathrm{a}, \mathrm{d}}$, Rob T.G.M. Essink PharmD, MPH ${ }^{\mathrm{e}}$, \\ Birgit H.B. van Benthem PhD ${ }^{\mathrm{f}}$, Stephanie Natsch PharmD, PhD ${ }^{\mathrm{g}}$, Cees M.P.M. Hertogh MD, PhD ${ }^{\mathrm{a}, \mathrm{b}}$ \\ a EMGO Institute for Health and Care Research, Amsterdam, The Netherlands \\ ${ }^{\mathrm{b}}$ Department of Nursing Home Medicine, VU University Medical Center, Amsterdam, The Netherlands \\ ${ }^{\mathrm{c}}$ Department of Public Health and Primary Care, Leiden University Medical Center, Leiden, The Netherlands \\ ${ }^{\mathrm{d}}$ The Netherlands Institute for Health Services Research, Utrecht, The Netherlands \\ ${ }^{\mathrm{e}}$ Dutch Institute for Rational Use of Medicine, Utrecht, The Netherlands \\ ${ }^{\mathrm{f}}$ Centre for Infectious Disease Control, National Institute for Public Health and the Environment, Bilthoven, The Netherlands \\ ${ }^{g}$ Department of Pharmacy, Radboud University Nijmegen Medical Centre, Nijmegen, The Netherlands
}

Keywords:

Nursing homes

assisted living facilities

antibiotics

drug resistance

infections

\begin{abstract}
A B S T R A C T
Introduction: The common occurrence of infectious diseases in nursing homes and residential care facilities may result in substantial antibiotic use, and consequently antibiotic resistance. Focusing on these settings, this article aims to provide a comprehensive overview of the literature available on antibiotic use, antibiotic resistance, and strategies to reduce antibiotic resistance.

Methods: Relevant literature was identified by conducting a systematic search in the MEDLINE and EMBASE databases. Additional articles were identified by reviewing the reference lists of included articles, by searching Google Scholar, and by searching Web sites of relevant organizations.

Results: A total of 156 articles were included in the review. Antibiotic use in long term care facilities is common; reported annual prevalence rates range from $47 \%$ to $79 \%$. Part of the prescribed antibiotics is potentially inappropriate.

The occurrence of antibiotic resistance is substantial in the long term care setting. Risk factors for the acquisition of resistant pathogens include prior antibiotic use, the presence of invasive devices, such as urinary catheters and feeding tubes, lower functional status, and a variety of other resident- and facilityrelated factors. Infection with antibiotic-resistant pathogens is associated with increased morbidity, mortality, and health care costs.

Two general strategies to reduce antibiotic resistance in long term care facilities are the implementation of infection control measures and antibiotic stewardship.

Conclusion: The findings of this review call for the conduction of research and the development of policies directed at reducing antibiotic resistance and its subsequent burden for long term care facilities and their residents.
\end{abstract}

Published by Elsevier Inc. on behalf of the American Medical Directors Association, Inc.
Elderly people living in nursing homes and residential care facilities are at increased risk of acquiring infectious diseases. This is because of several age-related factors, such as pathologic alterations to the immune system, functional disability, the presence of chronic diseases, and the use of invasive devices, such as urinary catheters and feeding tubes. ${ }^{1-3}$ In addition, several facility-related factors increase the risk of spread of infectious diseases, such as residents

This work was supported by a grant from The Netherlands Organisation for Health Research and Development (ZonMw, The Hague; grant number 205 100011).

* Address correspondence to Jenny T. van der Steen, PhD, VU University Medical Center, Department of Nursing Home Medicine, Van der Boechorststraat 7, 1081 BT Amsterdam, the Netherlands.

E-mail address: J.vandersteen@vumc.nl (J.T. van der Steen). living in close proximity and participating in social activities, and serial close contact of dependent residents with staff and medical equipment. ${ }^{1,3}$ Because of the presence of these biological and environmental factors, infectious diseases commonly occur in nursing homes and residential care facilities. An incidence rate ranging from 3 to 7 infections per 1000 resident-care days has been reported. ${ }^{4-6}$ In addition, a point-prevalence rate that varies between $6.7 \%$ and $7.6 \%$ was found for infections in nursing home residents. ${ }^{7}$ Whereas some studies report urinary tract infection (UTI) as the most common infectious disease in nursing homes and residential care facilities, 5,7-9 other studies report respiratory tract infection (RTI) as the most common infection. ${ }^{4,10-12}$ Skin and soft tissue infections (SSTIs) also represent a frequently reported type of infection. ${ }^{4,8,11}$ 
The common occurrence of infectious diseases in nursing homes and residential care facilities may result in substantial use of antibiotics in these settings, which in turn may enhance the development of antibiotic resistance. Over the past few decades, several studies have been published with regard to antibiotic use and resistance in these facilities. In addition, strategies have been proposed to reduce antibiotic resistance. This article aimed to integrate this information by providing a comprehensive overview of the literature on antibiotic use, antibiotic resistance, and strategies to reduce antibiotic resistance, thereby focusing on long term care facilities (nursing homes, where the main focus in on providing nursing care, and residential care facilities/ assisted living facilities, where the main focus is on providing a "home" for residents). Based on this literature overview, we formulate implications for future research and policy development.

\section{Methods}

Relevant literature was identified by conducting a systematic search in the MEDLINE and EMBASE databases. We used the following key words for the search in the MEDLINE database: "residential facilities [MeSH Terms] AND (anti-bacterial agents [MeSH Terms] OR drug resistance, microbial [MeSH terms])." For the search in the EMBASE database, the following key words were used: "('nursing home'/exp OR 'residential home'/exp) AND ('antibiotic agent'/exp OR 'antibiotic resistance'/exp)." Only publications in English, focused on humans, and listed in the database before May 5, 2011, were considered.

Evaluating the articles resulting from the systematic search, 2 researchers (L.v.B. and J.v.d.S.) identified 3 "areas of interest": antibiotic use, antibiotic resistance, and strategies to reduce antibiotic resistance. The same researchers developed general and "area of interest" specific inclusion and exclusion criteria, based on a set of articles they considered highly relevant (Box 1). The articles resulting from the search in the MEDLINE database were independently screened for inclusion by both researchers. In case of discrepancy in the judgment for relevance, the article was discussed until consensus was reached. Next, the articles resulting from the search in the EMBASE database were screened for relevance by the first researcher (L.v.B.); the second researcher (J.v.d.S.) screened a random sample of $10 \%$ and all articles that were included by the first researcher.

We additionally included articles by reviewing the reference lists of included articles, by hand searching Google Scholar, and by searching Web sites of relevant organizations (eg, the European Centre for Disease Prevention and Control, the American Medical Directors Association, the Society for Healthcare Epidemiology of America, the Association for Professionals in Infection Control and Epidemiology, and the World Health Organization).

\section{Results}

Figure 1 shows the flow diagram of the literature search. Of 978 articles retrieved with the systematic search in MEDLINE and EMBASE and of 18 articles identified otherwise (ie, by reviewing the reference lists of included articles, by hand searching Google Scholar, and by searching Web sites of relevant organizations), 159 met the inclusion criteria for 1 or more area(s) of interest (Box 1). Most of these 159 articles was allocated to the area of interest "antibiotic resistance" ( $\mathrm{n}=103)$. Fewer articles dealt with "antibiotic use" ( $\mathrm{n}=$ $44)$ or "strategies to reduce antibiotic resistance" $(n=16)$. Three articles that met the inclusion criteria were not cited because of difficulties interpreting results owing to an inadequate description of methods. Most of the 156 included articles were original articles $(\mathrm{n}=$ 107). Other types of articles were reviews $(n=30)$, letters $(n=10)$, reports $(n=3)$, editorials $(n=3)$, and guidelines $(n=3)$.
A high number of hits $(142,583)$ was retrieved in MEDLINE for the combination of MeSH terms: "anti-bacterial agents" OR "drug resistance, microbial." After adding the MeSH term "residential facilities," the number of hits decreased to 469 ( $0.33 \%$ of total). Similarly, a decrease from 398,900 to 699 hits $(0.18 \%$ of total) was observed in the number of hits retrieved with the search in EMBASE when the key words "'nursing home'/exp OR 'residential home'/exp" were added. Overall, $0.22 \%(1168 / 541,483)$ of the MEDLINE and EMBASE hits on antibiotics and antibiotic resistance focus on long term care facilities.

\section{Antibiotic Use in Nursing Homes and Residential Care Facilities}

\section{Incidence/Prevalence of Antibiotic Use}

Table 1 presents an overview of 26 studies that investigated the incidence and/or prevalence of antibiotic use among residents in long term care settings (inclusion criteria: Box 1). Of these, 22 were identified with the systematic search and 4 were identified otherwise.

In the United States and Canada, an incidence rate of 4.0 to 7.3 antibiotic courses per 1000 resident-days has been reported between 1991 and $2008 .{ }^{13-17}$ With regard to prevalence, between $47 \%$ and $79 \%$ of long term care facility residents in the United States, Canada, and Italy have been reported to receive at least 1 course of antibiotics during a study period of 1 year. ${ }^{14,15,17-22}$ In addition, 3 studies from the United States, Sweden, and Belgium reported that between 77\% and $88 \%$ of nursing home residents with infectious episodes were prescribed antibiotics. ${ }^{12,23,24}$ Further, 2 older cross-sectional studies conducted in the United States showed a point-prevalence rate of antibiotic use in nursing homes of $8.0 \%$ and $8.6 \%{ }^{17,25}$ Studies conducted in European countries reported a point-prevalence rate between $4.8 \%$ and $15.2 \%$. $7,8,26-28$

The infectious diseases for which antibiotics are most commonly prescribed in the long term care setting include UTIs, RTIs, and SSTIs. UTI is the most frequently reported indication for antibiotic prescribing, accounting for $32 \%$ to $66 \%$ of the prescriptions in nursing homes. RTI accounts for $15 \%$ to $36 \%$ of the prescriptions and SSTI for $13 \%$ to $18 \%$. $5,13-15,17,19,23-26,29-33$

\section{Factors Associated With Antibiotic Use}

We identified factors associated with antibiotic use in long term care facilities on the resident level, facility level, and geographical level. On the resident level, the use of invasive devices, such as urinary catheters or feeding tubes, was significantly associated with antibiotic use. ${ }^{13,35}$ Furthermore, higher rates of antibiotic use were found in residents with higher probabilities of nursing home discharge and in residents receiving extensive medical or rehabilitation services. ${ }^{13} \mathrm{~A}$ factor on the facility level is the facility type: Moro et $\mathrm{al}^{28}$ reported a higher prevalence of antibiotic use in residents of nursing homes (13.1\%) than in residents of residential care facilities (4.9\%) in Italy. In addition, Loeb et $\mathrm{al}^{35}$ found higher rates of antibiotic use in facilities with more health care aides per 100 residents. This finding may be explained by confounding, as facilities with more health care aides may accommodate residents who require more care. On the geographical level, antibiotic use has been reported to differ within and between countries. Blix et $\mathrm{al}^{29}$ reported large variation in antibiotic use among 133 nursing homes in Norway: from 4 to 44 defined daily doses per 100 bed days. Substantial variation in incidence of antibiotic use was also found between long term care facilities in the United States (8.0-14.8 antibiotic courses per 1000 resident care days per month). ${ }^{37}$ With regard to differences in antibiotic use between countries, Loeb et $\mathrm{al}^{35}$ reported that nursing homes in the United States prescribed significantly more antibiotics than Canadian nursing homes. Furthermore, The European Centre for 
Box 1. Inclusion criteria for articles identified with the systematic literature search

General inclusion criteria:

- Articles focusing on the following long term care settings: nursing homes, assisted living and/or residential care facilities.

General exclusion criteria:

- Articles focusing on other long term care settings, such as home care, (geriatric wards in) hospitals, and orphanages.

- Articles focusing on elderly persons in general.

- Articles focusing on subgroups of the nursing home/assisted living/residential care facility population (eg, residents with a specific condition (such as pneumonia or urinary tract infection), residents who were admitted to a hospital, and specific cases (case reports). An exception is the subarea of interest "appropriateness of antibiotic prescribing/use" (below), for which the subgroups "residents with dementia" and "residents with end-stage-disease" were eligible for inclusion.

- Articles focusing on antimicrobial agents groups other than "antibiotics" (ie, antivirals, antifungals, or antiparasitics).

- Letters, editorials and author comments, unless new empirical data were presented or a systematic literature review was provided.

- Research protocols.

- Articles not available in public domain.

For each article that met the above criteria, the area(s) of interest was/were determined. If the area of interest was one or more of those described below, the article was judged for relevance based on the criteria described for the respective area(s) of interest.

\section{Area of interest 1: Antibiotic use}

Included:

- Articles with a focus on antibiotic prescribing/use.

- Articles addressing at least one of the following subareas of interest:

- Prevalence/incidence of antibiotic prescribing/use: Articles were included in the overview table of prevalence/incidence of antibiotic use in long term care facilities if (1) these were primary research articles, (2) the antibiotic prescribing/use was measured on the resident level, (3) sufficient methodological information was available to interpret the findings, and (4) the prevalence/incidence was measured without or before the implementation of an intervention.

- Appropriateness of antibiotic prescribing/use

\section{Excluded:}

- Articles focusing on the management of infectious diseases in general.

- Articles describing randomized clinical trials (RCT) that examined the effectiveness of one type of antibiotic versus another.

\section{Area of interest 2: Antibiotic resistance}

Included:

- Articles focusing on the epidemiology, prevalence/incidence, risk factors and/or consequences of antibiotic resistance.

Excluded:

- Articles focusing on the molecular biology or molecular epidemiology of resistant pathogens (eg, typing of resistant strains), with no representative data on incidence/prevalence at the facility level.

- Outbreak reports of infections with antibiotic-resistant pathogens, as these do not provide a general overview of antibiotic resistance in the long term care setting.

- Articles focusing on community-acquired resistance (eg, by sampling residents at admission to a long term care facility).

\section{Area of interest 3: Strategies to reduce antibiotic resistance}

Included:

- Articles providing an overview of strategies to decrease antibiotic resistance.

Excluded:

- Articles focusing on the prevention of emergence/spread of specific resistant pathogens (eg, MRSA).

- Articles focusing on specific interventions to reduce antibiotic resistance (eg, hand washing).

- Articles focusing on infection control in general, without a specific focus on the control of infections with resistant pathogens. 


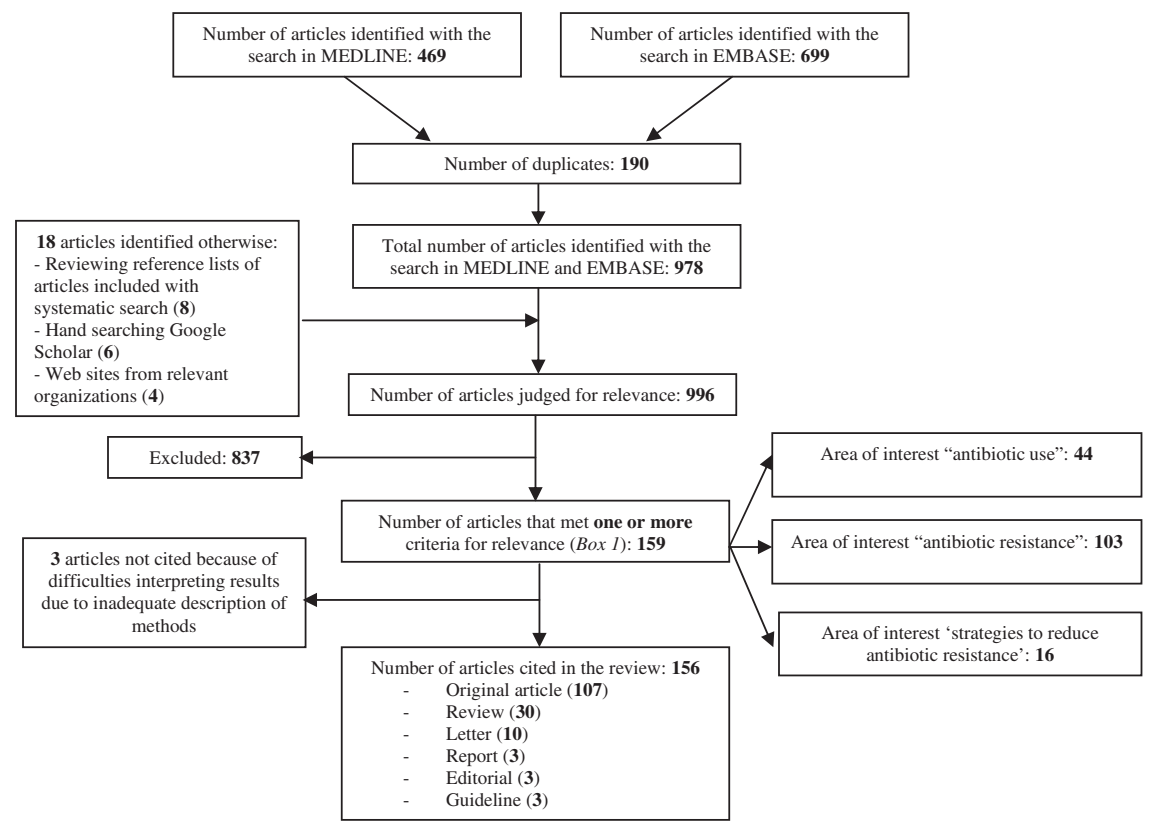

Fig. 1. Flow diagram of the literature search.

Disease Prevention and Control funded 2 related projects (the European Surveillance of Antimicrobial Consumption [ESAC] project and the Healthcare-Associated Infections in Long-term care Facilities [HALT] project) that reported substantial variation in antibiotic use among European nursing homes. Although their results are derived from a high number of nursing homes (304 and 117 respectively) in a high number of countries (19 and 13 respectively), drawing conclusions was complicated by the fact that a disproportionate number of cases was provided by nursing homes in only 3 countries (ie, Belgium, Italy, and Northern Ireland). ${ }^{38,39}$ However, weighted analyses (in this case by randomly selecting 5 nursing homes per country) resulted in similar conclusions: there was large variation in antibiotic prescription rates among European countries, ranging from 1.4\% in Germany and Latvia to $19.4 \%$ in Northern Ireland in April 2009 and from $1.2 \%$ in Latvia to $13.4 \%$ in Finland in November $2009 .{ }^{27}$

\section{Appropriateness of Antibiotic Use}

Diagnosing infectious diseases can be challenging in the longterm care setting for several reasons. Residents often present with atypical symptoms, have several chronic diseases (eg, diabetes or heart failure), may have hearing and speech difficulties, and may be cognitively impaired. In addition, diagnostic resources are often limited and obtaining appropriate specimens from residents may be difficult. ${ }^{2,9,13,19,40-42}$ As a result, the prescribing of antibiotics often occurs empirically in the long term care setting. The appropriateness of this empiric use of antibiotics, either in terms of whether antibiotics are indicated or in terms of selecting the right drug regimen, dosage, of treatment duration, has been investigated in several studies, thereby using various criteria. Zimmer et $\mathrm{al}^{25}$ reviewed the use of antibiotics in more than 2000 nursing home patients and judged evidence to start antibiotic treatment as adequate in $62 \%$ of cases. This judgment was based on criteria for appropriateness that had been developed by an expert panel. In another study, only $49 \%$ of 120 antibiotic prescriptions were considered appropriate. The primary reason for rating a prescription as not appropriate in this study was that a more effective antibiotic agent was recommended by infectious disease specialists and a hospital pharmacist (ie, in $71 \%$ of the cases). ${ }^{30}$ The same percentage of appropriate antibiotic prescriptions (49\%) was found by Loeb et al, ${ }^{14}$ with the least appropriate prescriptions in UTI (28\%) and more appropriate prescriptions in RTI (58\%) and SSTI (65\%). In the latter study, appropriateness of antibiotic prescribing was judged based on fulfillment of diagnostic criteria derived from definitions of infections in long term care facilities, as developed by McGeer et al. ${ }^{43}$ Clinical situations in which antibiotics are often prescribed inappropriately are viral respiratory infections and asymptomatic bacteriuria, whereas antibiotic treatment for these conditions is not recommended. ${ }^{40}$ Warren et $\mathrm{al}^{17}$ reported that of more than 2000 antibiotic prescriptions in nursing home residents, $13 \%$ were for viral respiratory infection and $9 \%$ for asymptomatic bacteriuria. The same percentage of inappropriate prescriptions for asymptomatic bacteriuria was found in another study. ${ }^{19}$

A specific domain in the determination of appropriateness of antibiotic prescribing is the use of antibiotics at the end of life. As early as 1979, it was observed that antibiotics were withheld in nursing home residents with end-stage disease who developed fever (ie, a proxy for an infectious disease). ${ }^{44}$ There is an ongoing debate about the appropriateness of antibiotic prescribing in patients at the end of life who develop RTIs, as the effect on neither life prolongation nor discomfort relief is clear. ${ }^{45-48}$

\section{Adverse Effects}

Even when antibiotics are prescribed appropriately, they pose a risk in terms of adverse effects. This risk has been reported to be elevated in the elderly. ${ }^{49,50}$ As older persons often use multiple drugs, adverse effects owing to drug interactions can be an issue. In addition, elderly are more susceptible to adverse drug reactions as a result of decreased kidney and liver function and the presence of multimorbidity. Furthermore, elderly who are being treated or have recently been treated with antibiotics are at increased risk of Clostridium difficile-associated diarrhea. ${ }^{9,45,49}$ Nevertheless, the greatest concern in terms of adverse consequences of antibiotic use is the development of antibiotic resistance, which potentially causes both an individual burden and a threat for public health. $9,45,49,51$ 
Antibiotic Resistance in Nursing Homes and Residential Care Facilities

\section{Incidence and Prevalence of Antibiotic Resistance}

We identified 60 studies in 14 countries that investigated the incidence or prevalence of antibiotic-resistant pathogens in long term care facilities. ${ }^{18,22,52-109}$ We found that colonization or infection of residents has been studied most commonly for methicillin-resistant Staphylococcus aureus (MRSA), multidrug resistant gram-negative bacteria (MDRGN), and vancomycin-resistant Enterococci (VRE). Trick et al ${ }^{103}$ reported colonization with at least 1 of these resistant pathogens in $43 \%$ of the persons residing in a long term care facility $(n=117)$ in the United States. Other studies from the United States reported MRSA colonization prevalence rates ranging from $8 \%$ to $82 \%$ between 1991 and 2000, and from $11 \%$ to $59 \%$ between 2001 and 2011. ${ }^{18,53,54,61,73,75,76,78,81,83,86,89,91,93,98,99,102}$ With regard to MDRGN and VRE, prevalence rates ranging from $23 \%$ to $51 \% 63,86,91,96$ and from $1 \%$ to $19 \%$ 60,86,91 were reported, respectively. O'Fallon et al ${ }^{87}$ found that $31 \%$ of long term care facility residents $(n=135)$ were colonized by at least 1 multidrug-resistant gram-negative organism at baseline of a cohort study. They also found that $39 \%$ of the residents acquired at least 1 of these organisms during the study period of 1 year, many of whom (62\%) had not been colonized at baseline.

European studies have also addressed antibiotic resistance. The highest prevalence rate of MRSA colonization (38\%) has been reported among residents $(n=109)$ of long term care facilities in France, ${ }^{62}$ and prevalence rates varying between $17 \%$ and $22 \%$ were found in nursing home residents $(159<\mathrm{n}<3037)$ in the United Kingdom. ${ }^{52,65,97}$ A lower MRSA colonization prevalence rate has been reported in Italy ( $8 \%$ and $19 \%, \mathrm{n}=551$ and $\mathrm{n}=88$ respectively), ${ }^{22,82}$ Slovenia ( $9 \%$ and $12 \%, \mathrm{n}=107$ and $\mathrm{n}=127$ respectively), ${ }^{56,106}$ Ireland ( $9 \%$ and $10 \%, \mathrm{n}=743$ and $\mathrm{n}=754$ respectively), ${ }^{88}$ and Belgium $(5 \%, \mathrm{n}=2857$ and $\mathrm{n}=2908) .{ }^{69,100}$ Prevalence rates were substantially lower in studies from the Northern European countries Germany $(1.1 \%, \mathrm{n}=3236),{ }^{105}$ Finland $(0.9 \%, \mathrm{n}=$ $213),{ }^{71}$ and the Netherlands $(0.2 \%-0.8 \%, 204<\mathrm{n}<89,573$ [the sample size of 89,573 is based on the number of isolates analyzed by laboratories; the other reported sample sizes are based on the number of residents]). ${ }^{59,66,67,101,107}$ Colonization with resistant pathogens other than MRSA during residency in long term care facilities has been reported in France (an increase in extended-spectrum $\beta$-lactamase-producing pathogens in the period 1996-2006), ${ }^{84}$ Ireland (prevalence of multidrug resistant Escherichia coli: $40.5 \%$ of the residents [ $\mathrm{n}=294]$ ), ${ }^{95}$ and Germany (prevalence of vancomycin-resistant Enterococci: $4.3 \%$ of the residents $[\mathrm{n}=188]){ }^{110}$

\section{Risk Factors for Colonization or Infection with Antibiotic-resistant Organisms}

Table 2 presents an overview of resident and facility-related characteristics that were identified as significant risk factors for colonization or infection with antibiotic-resistant organisms in 2 or more articles. At the resident level, prior antibiotic treatment was most frequently reported as a risk factor for colonization or infection with antibiotic-resistant organisms, followed by the presence of invasive devices, such as urinary catheters or feeding tubes. Another frequently reported risk factor is lower functional status, which may be explained by the fact that residents with a lower functional status have more frequent contact with health care workers and therefore more opportunities for acquisition of antibiotic-resistant organisms. ${ }^{86,103,105}$ Other risk factors that are related to the physical status of residents include the presence of decubitus ulcers, the presence of wounds, urinary incontinence, the presence of comorbidities, and fecal incontinence. In addition, several articles report prior hospitalization as a risk factor, which suggests that the hospital is a source of antibiotic-resistant organisms. Nevertheless, $\mathrm{Hsu}^{111}$ did not find an association between prior hospitalization and MRSA carriage in nursing home residents and argued that nursing homes serve as reservoirs of antibiotic-resistant pathogens as well. This was supported by other authors, who identified nursing home stay as a risk factor for colonization with MRSA at hospital admission. ${ }^{112-114}$ Both "longer" and "shorter" length of stay in long term care facilities have been associated with increased risk of colonization or infection with antibiotic-resistant organisms. Prolonged duration of stay in the facility may increase the likelihood of acquisition of antibiotic-resistant organisms from other colonized residents or health care workers. ${ }^{86}$ With regard to the risk factor "shorter length of stay in the facility," von Baum et al ${ }^{105}$ argue that this association may be confounded by prior hospitalization of residents admitted to a long term care facility. Other reported risk factors on the resident level include prior colonization by antibiotic-resistant organisms, male sex, higher intensity of nursing care, higher age, and lower cognitive status.

A lack of infection control policy is the most frequently reported facility-related factor that is associated with an increased risk of becoming colonized or infected with antibiotic-resistant organisms. This includes a lack of hygienic measures, such as hand washing, the use of gloves, cough etiquette, and barrier precautions. ${ }^{115}$ Other factors on the facility level include a number of factors related to staffing (ie, higher patient-to-staff ratio, frequent staff turnover, and staffing by nonprofessional personnel), an increased number of residents per bedroom, increased resident-to-resident contact, increased facility size, and limited facilities for hand washing.

\section{Consequences of Infection With Antibiotic-Resistant Organisms}

We identified consequences of infection with antibiotic-resistant organisms for public health, long term care facilities, and residents. Croft et al ${ }^{145}$ describe that the general impact of antibiotic resistance on public health and its costs are unknown owing to the complexity of estimating the burden of the problem. Nevertheless, experts agree on the assumption that antibiotic resistance results in increased costs and worse outcomes through higher morbidity and mortality. For longterm care facilities, it has indeed been described that morbidity resulting from infection with antibiotic-resistant organisms results in increased costs for treatment of residents, more frequent hospitalization, and the implementation of measures to control transmission of the resistant organism within the facility (eg, because of performing isolation procedures and screening of residents and staff). ${ }^{113,146,147}$ On the resident level, infection with antibiotic-resistant organisms has been associated with higher mortality compared with infection with antibiotic-susceptible organisms. ${ }^{87}$ In addition, Suetens et al ${ }^{147}$ reported a significantly higher risk of 36-month mortality in residents with MRSA colonization at baseline than in noncolonized residents, after adjustment for comorbidities and other potential confounders. This association was significant only in residents with advanced cognitive impairment, which may be explained by different therapeutic approaches in this population, such as less frequent hospital referral and withholding of treatment in residents with severe dementia. Another consequence reported on the resident level involves quality of life. Loeb et $\mathrm{al}^{148}$ investigated the quality of life of a small number of residents $(n=14)$ colonized with multiresistant organisms and found a trend toward more depressive symptoms, dysfunctional behavior, dependency in activities of daily living, and lower healthrelated quality of life. This trend toward worse quality of life may be related to isolation precautions, which may impede opportunities for residents to socialize or participate in group activities. ${ }^{113,148}$

\section{Strategies to Reduce Antibiotic Resistance in Long Term Care Settings}

\section{Implementation of Infection Control Measures}

Infection control refers to measures directed at preventing or decreasing the emergence and spread of infectious diseases. This 
Table 1

Studies on the Prevalence/Incidence of Antibiotic Use in Long Term Care Facilities

\begin{tabular}{|c|c|c|c|c|c|c|c|}
\hline Author / Reference & Published & Study Design & Study Setting & Study Population & Follow-up & Outcome Measure & Findings \\
\hline \multicolumn{8}{|c|}{ Prevalence/incidence of antibiotic use reported for residents } \\
\hline Zimmer et $\mathrm{al}^{25}$ & 1986 & $\begin{array}{l}\text { Cross-sectional } \\
\text { study }\end{array}$ & $\begin{array}{l}42 \text { skilled nursing facilities in the } \\
\text { United States }\end{array}$ & 1748 residents & - & $\begin{array}{l}\text { Prevalence of } \\
\text { antibiotic use }\end{array}$ & $\begin{array}{l}\text { - } 8.6 \% \text { of the residents }(\mathrm{n}=151) \text { received } \\
\text { antibiotics on the day of the survey }\end{array}$ \\
\hline $\begin{array}{l}\text { Jacobson and } \\
\text { Strausbaugh }^{33}\end{array}$ & 1990 & $\begin{array}{l}\text { Prospective } \\
\text { observational } \\
\text { study }\end{array}$ & $\begin{array}{l}\text { A nursing home care unit at a } \\
\text { Department of Veterans Affairs } \\
\text { Medical Center in the United States }\end{array}$ & 231 residents & 9 months & $\begin{array}{l}\text { Prevalence of } \\
\text { antibiotic use }\end{array}$ & $\begin{array}{l}\text { - } 51 \% \text { of the residents }(n=188) \text { received at } \\
\text { least } 1 \text { course of antibiotics }\end{array}$ \\
\hline Warren et $\mathrm{al}^{17}$ & 1991 & $\begin{array}{l}\text { Retrospective } \\
\text { study }\end{array}$ & 52 nursing homes in the United States & 3899 residents & 12 months & $\begin{array}{l}\text { Prevalence/incidence } \\
\text { of antibiotic use }\end{array}$ & $\begin{array}{l}\text { - The prevalence of antibiotic use on the } \\
\text { first day of study was } 8 \%(\mathrm{n}=312 \\
\text { residents) } \\
\text { - } 54 \% \text { of the residents }(\mathrm{n}=2105) \text { received } \\
\text { at least } 1 \text { antibiotic course during the } \\
\text { study period } \\
\text { - The incidence over } 12 \text { months was } 4.6 \\
\text { antibiotic courses per } 1000 \text { resident-days }\end{array}$ \\
\hline Lee et $\mathrm{al}^{32}$ & 1992 & $\begin{array}{l}\text { Prospective } \\
\text { observational } \\
\text { study }\end{array}$ & 7 nursing homes in the United States & 1031 residents & $\begin{array}{l}3 \text { months } \\
\text { (3 facilities) or } \\
4 \text { months } \\
\text { (4 facilities) }\end{array}$ & $\begin{array}{l}\text { Prevalence of } \\
\text { antibiotic use }\end{array}$ & $\begin{array}{l}\text { - } 33 \% \text { of the residents }(n=340) \text { received at } \\
\text { least } 1 \text { course of antibiotics }\end{array}$ \\
\hline Yakabowich et $\mathrm{al}^{20}$ & 1994 & $\begin{array}{l}\text { Quasi-experimental } \\
\text { study }\end{array}$ & 88 nursing homes in Canada & 6848 residents & $\begin{array}{l}3 \text { years ( } 1 \text { year } \\
\text { before an } \\
\text { intervention was } \\
\text { implemented and } \\
2 \text { years thereafter) }\end{array}$ & $\begin{array}{l}\text { Prevalence of } \\
\text { antibiotic use }\end{array}$ & $\begin{array}{l}\text { - } 47 \% \text { of the residents }(\mathrm{n}=3219) \text { received } \\
\text { antibiotics in the year before the } \\
\text { intervention was implemented (this } \\
\text { percentage remained the same in the } \\
2 \text { years after the intervention was } \\
\text { implemented) }\end{array}$ \\
\hline Montgomery et a $1^{19}$ & 1995 & Retrospective study & $\begin{array}{l}\text { Approximately } 100 \text { nursing homes in } \\
\text { a province in Canada }\end{array}$ & 2093 residents & 12 months (1986) & $\begin{array}{l}\text { Prevalence of } \\
\text { antibiotic use }\end{array}$ & $\begin{array}{l}\text { - } 57 \% \text { of the residents }(\mathrm{n}=1201) \text { received } \\
\text { at least } 1 \text { course of systemic antibiotics, } \\
26 \%(\mathrm{n}=543) \text { received at least } 1 \text { course of } \\
\text { topical antibiotics, and } 16 \%(\mathrm{n}=345) \\
\text { received at least } 1 \text { course of ophthalmic } \\
\text { antibiotics. Overall, } 70 \% \text { of the residents } \\
(\mathrm{n}=1455) \text { received at least } 1 \text { course of } \\
\text { any antibiotic type }\end{array}$ \\
\hline Lee et $\mathrm{al}^{5}$ & 1996 & $\begin{array}{l}\text { Prospective } \\
\text { observational } \\
\text { study }\end{array}$ & $\begin{array}{l}\text { One private community skilled nursing } \\
\text { facility in the United States }\end{array}$ & 585 residents & 20 months & $\begin{array}{l}\text { Prevalence of } \\
\text { antibiotic use }\end{array}$ & $\begin{array}{l}\text { - } 54 \% \text { of the residents ( } \mathrm{n}=316 \text { ) received } 1 \\
\text { or more antibiotic courses }\end{array}$ \\
\hline Mylotte ${ }^{15}$ & 1996 & $\begin{array}{l}\text { Prospective } \\
\text { observational } \\
\text { study }\end{array}$ & $\begin{array}{l}\text { A skilled nursing facility located within } \\
\text { a public, university-affiliated hospital } \\
\text { in the United States }\end{array}$ & 156 residents & 12 months & $\begin{array}{l}\text { Prevalence/incidence } \\
\text { of antibiotic use }\end{array}$ & $\begin{array}{l}\text { - } 71 \% \text { of the residents }(\mathrm{n}=111) \text { received at } \\
\text { least } 1 \text { course of antibiotics (in 1989) } \\
\text { - The incidence of antibiotic use was } 6.1 \\
\text { antibiotic courses per } 1000 \text { resident-days } \\
\text { (in 1989) }\end{array}$ \\
\hline Mylotte $^{16}$ & 1999 & $\begin{array}{l}\text { Prospective } \\
\text { observational } \\
\text { study }\end{array}$ & $\begin{array}{l}\text { Four long term care facilities in the } \\
\text { United States }\end{array}$ & $\begin{array}{l}\text { Two facilities with } 120 \\
\text { beds and } 2 \text { facilities } \\
\text { with } 160 \text { beds }\end{array}$ & $\begin{array}{l}20 \text { to } 26 \text { months } \\
\text { (varying per } \\
\text { facility) }\end{array}$ & $\begin{array}{l}\text { Incidence of } \\
\text { antibiotic use }\end{array}$ & $\begin{array}{l}\text { - The mean incidence of antibiotic use } \\
\text { varied between } 4.0 \text { and } 7.2 \text { antibiotic } \\
\text { courses per } 1000 \text { resident-days }\end{array}$ \\
\hline Loeb et $\mathrm{al}^{14}$ & 2001 & $\begin{array}{l}\text { Prospective } \\
\text { observational } \\
\text { study }\end{array}$ & $\begin{array}{l}22 \text { facilities in Canada ( } 10 \text { chronic care } \\
\text { facilities and } 12 \text { acute care hospitals } \\
\text { with chronic care beds) }\end{array}$ & 3656 residents & 12 months & $\begin{array}{l}\text { Prevalence/incidence } \\
\text { of antibiotic use }\end{array}$ & $\begin{array}{l}\text { - } 66 \% \text { of the residents }(\mathrm{n}=2408) \text { received } \\
\text { at least } 1 \text { course of antibiotics } \\
\text { - The mean incidence across facilities was } \\
7.3 \text { antibiotic courses per } 1000 \text { resident- } \\
\text { days (facility range: } 2.9 \text { to } 13.9 \text { antibiotic } \\
\text { courses per } 1000 \text { resident-days) }\end{array}$ \\
\hline Warshaw et $\mathrm{al}^{34}$ & 2001 & Retrospective study & $\begin{array}{l}\text { Residents of nursing homes in the } \\
\text { United States }\end{array}$ & $\begin{array}{l}\text { A sample of } 1306 \\
\text { elderly who spent } \\
\text { some time in nursing } \\
\text { homes }\end{array}$ & 36 months & $\begin{array}{l}\text { Prevalence of } \\
\text { antibiotic use }\end{array}$ & $\begin{array}{l}\text { - The prevalence of antibiotic use was } 67 \% \\
(\mathrm{n}=874 \text { elderly })\end{array}$ \\
\hline Loeb et $\mathrm{al}^{21,35}$ & 2003, 2004 & $\begin{array}{l}\text { Prospective } \\
\text { observational } \\
\text { study }\end{array}$ & $\begin{array}{l}50 \text { nursing homes in Canada and the } \\
\text { United States }\end{array}$ & 9156 residents & 12 months & $\begin{array}{l}\text { Prevalence of } \\
\text { antibiotic use }\end{array}$ & $\begin{array}{l}\text { - } 79 \% \text { of the residents ( } \mathrm{n}=7233 \text { ) received } \\
1 \text { or more antibiotic courses }\end{array}$ \\
\hline
\end{tabular}


Table 1 (continued)

\begin{tabular}{|c|c|c|c|c|c|c|c|}
\hline Author / Reference & Published & Study Design & Study Setting & Study Population & Follow-up & Outcome Measure & Findings \\
\hline Moro et $\mathrm{al}^{28}$ & 2007 & $\begin{array}{l}\text { Point-prevalence } \\
\text { survey }\end{array}$ & $\begin{array}{l}15 \text { nursing homes and } 34 \text { residential } \\
\text { care facilities in Italy }\end{array}$ & $\begin{array}{l}1926 \text { residents (329 in } \\
\text { nursing homes and } \\
1597 \text { in residential } \\
\text { care facilities) }\end{array}$ & - & $\begin{array}{l}\text { Prevalence of } \\
\text { antibiotic use }\end{array}$ & $\begin{array}{l}\text { - } 12.1 \% \text { of the residents }(\mathrm{n}=234) \text { received } \\
\text { at least } 1 \text { course of systemic antibiotics } \\
\text { on the day of the survey }\end{array}$ \\
\hline Benoit et a $1^{13}$ & 2008 & Retrospective study & 73 nursing homes in the United States & 1780 residents & 6 months & $\begin{array}{l}\text { Prevalence/incidence } \\
\text { of antibiotic use }\end{array}$ & $\begin{array}{l}\text { - } 42 \% \text { of the residents }(\mathrm{n}=2017) \text { received } \\
1 \text { or more antibiotic courses } \\
\text { - Overall, residents received a mean of } 4.8 \text {. } \\
\text { antibiotic courses per } 1000 \text { resident-days }\end{array}$ \\
\hline Brugnaro et $\mathrm{al}^{22}$ & 2009 & Retrospective study & 2 long term care facilities in Italy & 551 residents & 12 months & $\begin{array}{l}\text { Prevalence of } \\
\text { antibiotic use }\end{array}$ & $\begin{array}{l}\text { - } 63 \% \text { of the residents }(\mathrm{n}=349) \text { received at } \\
\text { least } 1 \text { systemic antibiotic course }\end{array}$ \\
\hline Garazi et al ${ }^{18}$ & 2009 & $\begin{array}{l}\text { Cross-sectional } \\
\text { study }\end{array}$ & $\begin{array}{l}\text { A long term care facility in the } \\
\text { United States }\end{array}$ & 160 residents & 12 months & $\begin{array}{l}\text { Prevalence of } \\
\text { antibiotic use }\end{array}$ & $\begin{array}{l}\text { - } 77.7 \% \text { of the residents }(n=124) \text { received } \\
\text { at least } 1 \text { course of antibiotics }\end{array}$ \\
\hline Blix et $\mathrm{al}^{26}$ & 2010 & $\begin{array}{l}\text { Point-prevalence } \\
\text { survey }\end{array}$ & 44 nursing homes in Norway & 1473 residents & - & $\begin{array}{l}\text { Prevalence of } \\
\text { antibiotic use }\end{array}$ & $\begin{array}{l}\text { - } 15.2 \% \text { of the residents }(n=224) \text { received } \\
\text { antibiotics on the day of survey }\end{array}$ \\
\hline 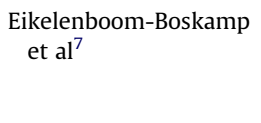 & 2011 & $\begin{array}{l}\text { Point-prevalence } \\
\text { survey }\end{array}$ & $\begin{array}{l}17,15 \text {, and } 24 \text { nursing homes (in } 2007 \text {, } \\
2008 \text {, and } 2009 \text {, respectively) in the } \\
\text { Netherlands }\end{array}$ & $\begin{array}{l}\text { 1275, } 1323, \text { and } 1772 \\
\text { residents (in 2007, } \\
\text { 2008, and 2009, } \\
\text { respectively) }\end{array}$ & - & $\begin{array}{l}\text { Prevalence of } \\
\text { antibiotic use }\end{array}$ & $\begin{array}{l}\text { - On average, } 6.6 \% \text { of the residents received } \\
\text { antibiotics on the day of the survey }\end{array}$ \\
\hline McClean et $\mathrm{al}^{27}$ & 2011 & $\begin{array}{l}\text { Point-prevalence } \\
\text { survey }\end{array}$ & $\begin{array}{l}\text { Part of the European Surveillance of } \\
\text { Antimicrobial Consumption survey: } \\
85 \text { nursing homes in } 15 \text { European } \\
\text { countries and } 2 \text { UK administrations }\end{array}$ & $\begin{array}{l}\text { 10,388 residents in } \\
\text { April } 2009 \text { and } 9430 \\
\text { residents in } \\
\text { November }\end{array}$ & - & $\begin{array}{l}\text { Prevalence of } \\
\text { antibiotic use }\end{array}$ & $\begin{array}{l}\text { - } 6.2 \% \text { of the residents }(\mathrm{n}=645) \text { and } 4.8 \% \\
\text { of the residents }(\mathrm{n}=450) \text { received } \\
\text { antibiotics on the day of the survey in } \\
\text { April and November, respectively. } \\
\text { Prevalence rate range: in April from } \\
\text { 1.4\% in Germany and Latvia to } 19.4 \% \text { in } \\
\text { Northern Ireland and in November from } \\
1.2 \% \text { in Latvia to } 13.4 \% \text { in Finland. }\end{array}$ \\
\hline \multicolumn{8}{|c|}{ ace of antibiotic use reported for infectious episodes among residents } \\
\hline Beck-Sague et $\mathrm{al}^{23}$ & 1994 & $\begin{array}{l}\text { Prospective } \\
\text { observational } \\
\text { study }\end{array}$ & 13 nursing homes in the United States & 1754 residents & 6 months & $\begin{array}{l}\text { Prevalence of } \\
\text { antibiotic use }\end{array}$ & $\begin{array}{l}\text { - Of the } 835 \text { infectious episodes that } \\
\text { occurred during the follow-up period, } \\
77 \%(n=646) \text { were treated with } \\
\text { antibiotics }\end{array}$ \\
\hline Moens et al ${ }^{12}$ & 1996 & Retrospective study & 35 nursing homes in Belgium & 2595 residents & 1 month & $\begin{array}{l}\text { Prevalence of } \\
\text { antibiotic use }\end{array}$ & $\begin{array}{l}\text { - Of the } 257 \text { residents with an infection, } \\
88 \%(n=226) \text { were treated with } \\
\text { antibiotics. }\end{array}$ \\
\hline Pettersson et $\mathrm{al}^{24}$ & 2008 & $\begin{array}{l}\text { Cross-sectional } \\
\text { study }\end{array}$ & 58 nursing homes in Sweden & 3002 residents & 3 months & $\begin{array}{l}\text { Prevalence/incidence } \\
\text { of antibiotic use }\end{array}$ & $\begin{array}{l}\text { - Of the } 889 \text { infectious episodes that } \\
\text { occurred during the follow-up period, } \\
84 \%(n=769) \text { were treated with } \\
\text { antibiotics } \\
\text { - The incidence of antibiotic use was } \\
1 \text { treatment per resident per year }\end{array}$ \\
\hline \multicolumn{8}{|c|}{ Prevalence/incidence of antibiotic use reported for specific types of infectious diseases in residents } \\
\hline Mott and Barker ${ }^{36}$ & 1988 & $\begin{array}{l}\text { Retrospective } \\
\text { study }\end{array}$ & $\begin{array}{l}\text { A skilled nursing facility in the United } \\
\text { States }\end{array}$ & 110 residents & 7 years & $\begin{array}{l}\text { Prevalence of } \\
\text { antibiotic use in } \\
3 \text { infection types }\end{array}$ & $\begin{array}{l}\text { - Of } 102 \text { residents who were treated in the } \\
\text { nursing home for RTI, } 79 \%(\mathrm{n}=81) \\
\text { received antibiotics } \\
\text { - Of } 66 \text { residents who were treated in the } \\
\text { nursing home for UTI, 89\% ( } \mathrm{n}=59) \\
\text { received antibiotics } \\
\text { - Of } 31 \text { residents who were treated in the } \\
\text { nursing home for skin infections, 90\% } \\
(\mathrm{n}=28) \text { received antibiotics }\end{array}$ \\
\hline Eriksen et al ${ }^{8}$ & 2004 & $\begin{array}{l}\text { Two annual } \\
\text { point-prevalence } \\
\text { surveys }\end{array}$ & $\begin{array}{l}\text { Between } 203 \text { and } 323 \text { long term care } \\
\text { facilities in Norway }\end{array}$ & $\begin{array}{l}\text { Between } 11,465 \text { and } \\
17,174 \text { residents }\end{array}$ & - & $\begin{array}{l}\text { Prevalence of } \\
\text { antibiotic use for } \\
\text { the } 4 \text { most } \\
\text { common infections } \\
\text { in long term care } \\
\text { settings }\end{array}$ & $\begin{array}{l}\text { - The prevalence rate range of antibiotic } \\
\text { use was } 5.5 \%-5.9 \%\end{array}$ \\
\hline
\end{tabular}


Table 2

Risk Factors* for Becoming Colonized or Infected with Antibiotic-Resistant Organisms in Long Term Care Facilities

\begin{tabular}{|c|c|c|c|c|}
\hline \multirow[b]{2}{*}{ Risk factor } & \multicolumn{4}{|c|}{ No. of Articles in Which Reported, by Type of Analysis (+ References) } \\
\hline & $\begin{array}{l}\text { No. of Articles in } \\
\text { Which Reported }\end{array}$ & Bivariable $^{\dagger}$ & Multivariable $^{\dagger}$ & Review \\
\hline \multicolumn{5}{|l|}{ Resident factors } \\
\hline Prior antibiotic treatment & 35 & $13^{18,21,70,96,103,105,116-122}$ & $12^{62,80,86,87,100,109,123-128}$ & $10^{2,41,42,113,115,129-133}$ \\
\hline $\begin{array}{l}\text { Presence of invasive devices } \\
\text { (eg, urinary catheter, feeding tube) }\end{array}$ & 29 & $7^{102,103,111,118,119,121,134}$ & $9^{62,94,96,100,105,125,127,128,135}$ & $13^{2,41,42,113,115,129-133,136-138}$ \\
\hline Lower functional status & 26 & $8^{53,68,77,96,102,109,111,139}$ & $7^{86,103,105,111,121,125,140}$ & $11^{2,41,113,115,129,130,132,133,136-138}$ \\
\hline Prior hospitalization & 18 & $10^{18,65,68,70,94,117,120-122,141}$ & $3^{100,105,123}$ & $5^{41,115,131,133,138}$ \\
\hline Presence of decubitus ulcers & 15 & $5^{102,105,111,117,142}$ & $5^{86,100,120,126,134}$ & $5^{41,113,115,132,138}$ \\
\hline Presence of wounds & 14 & $5^{53,62,70,102,142}$ & $1^{105}$ & $8^{2,41,113,129,131,132,136,137}$ \\
\hline $\begin{array}{l}\text { Prior colonization by antibiotic-resistant } \\
\text { organisms }\end{array}$ & 10 & $3^{18,103,118}$ & $3^{96,134,143}$ & $4^{2,41,113,129}$ \\
\hline Urinary incontinence & 7 & $2^{87,139}$ & $1^{134}$ & $4^{41,113,115,138}$ \\
\hline \multicolumn{5}{|l|}{ Presence of comorbidities } \\
\hline $\begin{array}{l}\text { - Diabetes mellitus and/or peripheral } \\
\text { vascular disease }\end{array}$ & 7 & $2^{102,120}$ & $1^{94}$ & $4^{2,41,113,115}$ \\
\hline - "Underlying illness" & 4 & - & - & $4^{41,42,130,138}$ \\
\hline - Renal disease/ insufficiency & 3 & $2^{18,102}$ & - & $1^{113}$ \\
\hline - Comorbidities in general & 3 & $1^{134}$ & - & $2^{41,129}$ \\
\hline - Prior pneumonia & 3 & $1^{102}$ & - & $2^{41,113}$ \\
\hline - Inflammatory bowel disease & 2 & $1^{102}$ & - & $1^{113}$ \\
\hline Male sex & 5 & $1^{142}$ & $3^{94,120,134}$ & $1^{113}$ \\
\hline Fecal incontinence & 4 & $1^{139}$ & $1^{86}$ & $2^{115,138}$ \\
\hline Higher intensity of nursing care & 4 & - & $1^{109}$ & $3^{41,129,133}$ \\
\hline \multicolumn{5}{|l|}{ Length of stay in the facility } \\
\hline - “longer" & 3 & - & - & $3^{41,42,113}$ \\
\hline$-\geq 4 y$ & 1 & - & $1^{86}$ & - \\
\hline$-1-4 y$ & 1 & - & $1^{100}$ & - \\
\hline$-<6$ mo & 2 & $2^{105,120}$ & - & - \\
\hline - "shorter" when comparing interquartile ranges & 2 & $2^{103,141}$ & - & - \\
\hline Higher age & 3 & $1^{120}$ & - & $2^{113,115}$ \\
\hline Lower cognitive status & 2 & - & $1^{120}$ & $1^{130}$ \\
\hline \multicolumn{5}{|l|}{ Facility factors } \\
\hline Lack of infection control policy & 5 & - & - & $5^{42,113,115,138,144}$ \\
\hline Higher patient-to-staff ratio & 5 & - & - & $5^{42,113,115,138,144}$ \\
\hline Frequent staff turnover & 4 & - & - & $4^{113,115,138,144}$ \\
\hline Staffing by nonprofessional personnel & 4 & - & - & $4^{113,115,138,144}$ \\
\hline \multicolumn{5}{|l|}{ Facility size } \\
\hline - Large & 4 & - & - & $4^{41,113,115,133}$ \\
\hline - Medium & 1 & - & $1^{105}$ & - \\
\hline Higher number of residents per bedroom & 3 & - & $1^{100}$ & $2^{42,113}$ \\
\hline More frequent resident-to-resident contact & 2 & - & - & $2^{138,144}$ \\
\hline Limited facilities for hand washing & 2 & - & - & $2^{42,113}$ \\
\hline
\end{tabular}

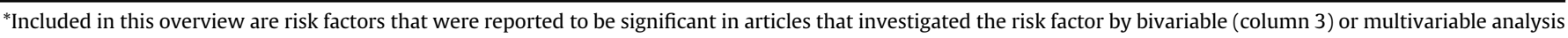
(column 4), and by systematic and nonsystematic review articles (column 5).

${ }^{\dagger}$ Risk factors that were identified in a study by both bivariable and multivariable analysis are listed only in the column "multivariable."

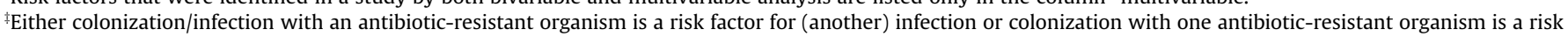
factor for colonization with another antibiotic-resistant organism.

results in a lower incidence of infectious diseases and antibiotic use, and in turn to a reduced emergence and spread of antibiotic-resistant organisms. Examples of infection control measures in the long term care facility include hand washing, the use of gloves, disinfection of surfaces, cough etiquette, appropriate ventilation, immunization of residents, and minimal use of invasive devices, such as urinary catheters and feeding tubes. ${ }^{1,21,113,131,149-151}$ Furthermore, important components of infection control programs include the assignment of a well-trained infection control practitioner to head the program, the assignment of an infection control committee, the dissemination of an infection control plan, staff education, ensuring sufficient administrative and financial support to undertake core infection control functions, and the surveillance of antibiotic-resistant organisms and antibiotic use. ${ }^{149-152}$ The implementation of infection control programs, however, can be challenging in long term care settings. Lack of personnel, high workload, insufficient training, and a lack of resources are examples of factors that can impair the implementation of infection control measures. $1,6,103,113,153-155$

Policy initiatives for infection control have been developed specific to the long term care setting. A number of guidelines on infection control in long term care facilities have been published, such as by the American Medical Directions Association, and by the Society for Healthcare Epidemiology of America and the Association for Professionals in Infection Control and Epidemiology. ${ }^{156,157}$ In Europe, the recently concluded HALT project investigated the distribution and characteristics of infection control programs in 117 nursing homes in 13 European countries, and found that there is room for improvement with regard to infection control policies. For example, only a minority of the nursing homes had assigned an infection control committee $(30.4 \%)$ or an infection control practitioner $(38.1 \%){ }^{39}$

Improving the Rational Use of Antibiotics (Antibiotic Stewardship)

Warnings not to abuse antibiotics date back to Alexander Fleming in the 1940 s. ${ }^{158}$ More recently, several initiatives have been taken in promoting rational antibiotic use in long term care settings. In 2000, Nicolle et $\mathrm{al}^{9}$ published a guideline with recommendations on antibiotic prescribing for RTI, UTI, SSTI, diarrhea, and fever of unknown origin. In another guideline, published by Loeb et al, ${ }^{40}$ minimum criteria for the initiation of antibiotics in long term care facilities were 
formulated. Both guidelines represent highly cited works. In addition to adherence to guidelines on antibiotic prescribing, other elements of antibiotic stewardship programs include physician education on antibiotic prescribing, providing feedback on prescriptions (eg, antibiotic use review by a pharmacist), monitoring appropriateness of antibiotic prescribing, providing resources for obtaining cultures for diagnosis, using restricted formularies, using antibiotic order forms, and limiting the use of broad-spectrum antibiotics. $9,25,131,152,159$ The involvement of nursing staff is considered important for the success of antibiotic stewardship programs, as the information on which physicians base treatment decisions is often derived from nursing assessments. $^{132,154}$ At the physician level, factors that need to be addressed in the successful implementation of antibiotic stewardship programs include knowledge and preferences regarding antibiotic use, and perceived expectations of the patient and the family of the patient with regard to antibiotic treatment. ${ }^{160}$

In the European setting, the availability of antibiotic stewardship resources was investigated by the ESAC project group. Data were obtained from 260 nursing homes in 17 countries. A finding that suggests room for improvement is that no specific guidelines for rational use of antibiotics in the long term care setting were available in $50 \%$ of the nursing homes. Furthermore, a restricted antibiotic formulary was used in only $16.2 \%$ of the facilities and the same percentage of facilities did not provide regular training of physicians on appropriate antibiotic prescribing. ${ }^{38}$

\section{Discussion}

The aim of this article was to provide an overview of the literature for the long term care setting (nursing homes and residential care facilities/assisted living) on each of the following topics: antibiotic use, antibiotic resistance, and strategies to reduce antibiotic resistance. This overview demonstrated that the use of antibiotics in long term care facilities is substantial and that antibiotic resistance is common. It also suggested that antibiotic resistance has an impact on individuals, facilities, and public health in terms of quality of life, morbidity, mortality, and health care costs. In addition, this overview identified a variety of risk factors for colonization or infection with antibiotic-resistant organisms in residents of long term care facilities. Furthermore, it described 2 general strategies to reduce antibiotic resistance in the long term care setting: the implementation of infection control measures and improving the rational use of antibiotics (ie, antibiotic stewardship).

Remarkably, fewer than $0.3 \%$ of the MEDLINE and EMBASE publications on antibiotic use and antibiotic resistance focus on long term care facilities. Research on these topics may be relatively underdeveloped in the long term care setting, compared with other health care settings, such as the hospital and primary care. Of the articles identified for the long term care setting, more were allocated to the area of interest "antibiotic resistance" (103/159) than to the area of interest "antibiotic use" (44/159), which indicates that relatively more research focuses on the former topic. A broad interest in antibiotic resistance concurs with the World Health Organization's theme of World Health Day 2011, during which the agency called on governments to undertake action with regard to the resistance problem in all health care settings under the slogan "no action today means no cure tomorrow."161

The ESAC project reported large variation among countries in antibiotic use for nursing home residents. The highest prevalence rates were found for northern European countries (ie, Northern Ireland and Finland). ${ }^{27}$ This is a remarkable finding, as in primary care settings, southern European countries account for the highest antibiotic use. ${ }^{162}$

Interestingly, some authors report that only $49 \%$ to $62 \%$ of the antibiotics in long term care facilities are prescribed appropriately $^{14,25,30}$; however, these studies based their findings on different criteria for judging appropriateness of antibiotic prescribing. The lack of a universally accepted definition for diagnosing infectious diseases and subsequent appropriate prescribing of antibiotics, ${ }^{163}$ in combination with the small number of studies conducted, complicates drawing conclusions on the appropriateness of antibiotic prescribing in long term care facilities.

In addition to prior antibiotic treatment and presence of invasive devices, such as urinary catheters and feeding tubes, lower functional status is one of the most frequently reported risk factors for becoming colonized or infected with antibiotic resistant organisms in long term care facilities. Some of the authors who identified this association by multivariable analysis suggest that this may be because residents with lower functional status have more frequent contact with health care workers. ${ }^{86,103,105}$ Another explanation, which we did not encounter in the retrieved literature, may be that residents with lower functional status are more vulnerable for the acquisition of infections because of a more compromised immune system.

The hospital is commonly regarded as a source of antibioticresistant pathogens from which transmission to other health-care setting occurs. Nonetheless, some studies retrieved with the literature search suggested that long term care facilities may serve as reservoirs for antibiotic-resistant pathogens as well. ${ }^{112-114}$ These studies focused on the epidemiology of transmission (eg, by determining prior nursing home stay in colonized patients admitted to the hospital), and could not draw firm conclusions with regard to the transmission of resistant strains from one health care facility to another. Studies focusing on molecular epidemiology, which were not addressed in this review, are better suitable to elucidate the role of the nursing home in the transmission of antibiotic-resistant pathogens. For example, a Dutch study on the distribution of MRSA isolates between 1998 and 2005 indicated nursing homes as a potential intermediate for MRSA transmission from the community to the hospital. ${ }^{164}$

This review addressed antibiotic use and antibiotic resistance as separate issues, because the studies on antibiotic use differ from those on antibiotic resistance in terms of study setting and design. Comparing these studies across countries provides inconsistent evidence for an association between antibiotic use and antibiotic resistance. For example, Germany, a country with a low antibiotic use pointprevalence $(1.4 \%),{ }^{27}$ is reported to have a low prevalence of MRSA resistance when compared with other European countries $(1.1 \%) .{ }^{105}$ In Italy, with a moderate antibiotic use point-prevalence $(8.4 \%),{ }^{28}$ resistance rates were also moderate ( $8 \%$ to $19 \%){ }^{22,82}$ By contrast, in Northern Ireland (19.4\%) and Finland (13.4\%), ${ }^{27}$ antibiotic use point-prevalence was reported to be among the highest in Europe, but reported MRSA prevalence was moderate to low in these countries ( $9 \%-10 \%$ and $0.9 \%$, respectively). ${ }^{71,88}$ This inconsistent evidence for an association between antibiotic use and resistance on the country level may be explained by antibiotic resistance not only being associated with antibiotic use, but also with the extent to which infection control activities are implemented in long term care facilities.

Many articles that we retrieved through the literature search focused on specific interventions to reduce antibiotic resistance, such as hand washing and implementation of guidelines. Such articles were not included this review, as we aimed to provide a general overview of strategies to reduce antibiotic resistance rather than an overview of effectiveness of specific interventions. This explains the relatively low number of articles allocated to the area of interest "strategies to reduce antibiotic resistance" (16/159); clearly, a higher number of articles would have been allocated to this area of interest if specific interventions would have been included.

We also did not include articles that addressed antibiotic use and resistance in subgroups of long term care facility residents (eg, residents with pneumonia or residents with invasive devices, such as 
urinary catheters and feeding tubes). Instead, a rather broad focus on the general long term care facility population was chosen to ensure a comprehensive situation analysis without elaboration on subgroup details.

Another limitation is that only publications in English were considered. As a consequence, limited data on antibiotic use and resistance were included for other countries that mainly publish on patterns of antibiotic use and resistance in their native language. Other possible limitations are that only 2 databases were searched (MEDLINE and EMBASE) and that only keywords and no free text terms were used in the literature search. Therefore, additional possibly relevant articles may have been missed. We are, however, confident that the most relevant literature is included in this review, as many articles identified with the search strategy were encountered in the reference lists of other identified articles. Furthermore, additional relevant articles were included by reviewing the reference lists of included articles, by hand searching Google Scholar, and by searching Web sites of relevant organizations.

The relatively low percentage of publications on antibiotic use and resistance that focus on long term care facilities indicates a need for more research specific to this setting. In addition, further research is required to elucidate the extent of the problem of inappropriate antibiotic prescribing. Although it may promote comparability of results if future studies used a universal definition for appropriateness of antibiotic prescribing, it is questionable whether this is feasible. Different countries use different guidelines for diagnosis and treatment of infectious diseases in long term care residents, which may call for definitions tailored to the specific situation in these countries. Other areas for future research include further elucidation of the role of nursing homes as a possible source of antibioticresistant pathogens, investigation of the association between lower functional status and becoming colonized or infected with antibioticresistant organisms, and possible associations between antibiotic use rates and antibiotic resistance rates within countries, also addressing the degree to which resistance is avoidable.

The serious consequences of antibiotic resistance in long term care facilities provide a rationale for the conduction of research and the development of policies directed at reducing antibiotic resistance in these facilities. These should focus on both the implementation of infection control measures and antibiotic stewardship. With regard to infection control measures, training of health care personnel is crucial to implement hygiene practice. To establish a sustainable training program, facilities should allocate adequate resources. The assignment of an infection control committee or an infection control practitioner may facilitate the development and sustainability of such a program. With regard to antibiotic stewardship, it is important that physicians are well educated on the diagnosis and treatment of infectious diseases in residents, and that this education is based on relevant guidelines. Other measures to facilitate appropriate antibiotic prescribing include monitoring of antibiotic use, encouraging physicians and pharmacists to develop and regularly review formularies, and promoting specimen culturing in residents with suspected infection. It is important to realize that, although infection control measures and antibiotic stewardship address different aspects of the antibiotic resistance problem, they are closely interrelated. For example, the effect of rational antibiotic prescribing by physicians is abolished if no attention is paid to infection control measures by nursing staff. Therefore, strategies to combat antibiotic resistance are more likely to be successful if they are multifaceted. Hence, they require close collaboration among all disciplines involved.

Differences between types of long term care facilities should be taken into account in research and policy development to reduce antibiotic resistance. Whereas residential care facilities or assisted living facilities generally have a main focus on providing a "home" for their residents, the focus of nursing homes is on providing nursing care. Consequently, the way in which medical care is organized often differs between these types of facilities. For example, in US nursing homes, medical care may include provision of antibiotics and intravenous fluids, whereas such services are not directly available in assisted living environments. ${ }^{165}$ This difference in antibiotic availability may explain the finding of Moro et $\mathrm{al}^{28}$ that the prevalence of antibiotic use was higher in nursing homes than in residential care facilities.

The organization of medical care in long term care facilities also differs among countries, because of distinct health care systems. This may result in international variation in antibiotic use, antibiotic resistance, and opportunities to implement infection control and antibiotic stewardship measures. As a consequence, extrapolation of research and policy to other countries or other long term care settings is frequently complicated. Therefore, research on the impact of different types of long term care facilities and different health care systems on antibiotic use and resistance is needed (eg, collaborative cross-national studies), to explain differences in antibiotic use and resistance between countries and health care settings.

Despite the potential limitations, we believe that this review clearly points out that antibiotic use and antibiotic resistance in the long term care setting is common and that it causes substantial burden to individuals, long term care facilities, and public health. This calls for the conduction of research and the development of policies directed at reducing the antibiotic resistance and subsequent burden for long term care facilities and their residents.

\section{References}

1. Richards CLJ, Steele L. Antimicrobial-resistant bacteria in long-term care facilities: infection control considerations. J Am Med Dir Assoc 2003;4: S110-S114

2. Nicolle LE, Strausbaugh LJ, Garibaldi RA. Infections and antibiotic resistance in nursing homes. Clin Microbiol Rev 1996;9:1-17.

3. Garibaldi RA. Residential care and the elderly: The burden of infection. J Hosp Infect 1999;43:S9-S18.

4. Bula CJ, Ghilardi G, Wietlisbach V, et al. Infections and functional impairment in nursing home residents: A reciprocal relationship. J Am Geriatr Soc 2004; 52:700-706.

5. Lee YL, Thrupp LD, Lee R, et al. Infection surveillance and antibiotic utilization in a community-based skilled nursing facility. Aging (Milano) 1996;8: 113-122.

6. Smith PW. Nursing home infection control: A status report. Infect Control Hosp Epidemiol 1998;19:366-369.

7. Eikelenboom-Boskamp A, Cox-Claessens JHM, Boom-Poels PGM, et al. Threeyear prevalence of healthcare-associated infections in Dutch nursing homes. J Hosp Infect 2011;78:59-62.

8. Eriksen HM, Iversen BG, Aavitsland P. Prevalence of nosocomial infections and use of antibiotics in long-term care facilities in Norway, 2002 and 2003. J Hosp Infect 2004;57:316-320.

9. Nicolle LE, Bentley DW, Garibaldi R, et al. Antimicrobial use in long-term-care facilities. SHEA Long-Term-Care Committee. Infect Control Hosp Epidemiol 2000;21:537-545.

10. Palumbo A, Moll M, Ostroff S. Description of healthcare associated infections in long-term care facilities in Pennsylvania. Presentation number 15-248. Am J Infect Control 2012;33:105-111.

11. Stevenson KB, Moore J, Colwell H, Sleeper B. Standardized infection surveillance in long-term care: Interfacility comparisons from a regional cohort of facilities. Infect Control Hosp Epidemiol 2005;26:231-238.

12. Moens GF, Haenen R, Jacques P. The prevalence of infections in nursing homes in Belgium. J Hosp Infect 1996;34:336-337.

13. Benoit SR, Nsa W, Richards CL, et al. Factors associated with antimicrobial use in nursing homes: A multilevel model. J Am Geriatr Soc 2008;56:2039-2044.

14. Loeb M, Simor AE, Landry L, et al. Antibiotic use in Ontario facilities that provide chronic care. J Gen Intern Med 2001;16:376-383.

15. Mylotte JM. Measuring antibiotic use in a long-term care facility. Am J Infect Control 1996;243:174-179.

16. Mylotte JM. Antimicrobial prescribing in long-term care facilities: Prospective evaluation of potential antimicrobial use and cost indicators. Am J Infect Control 1999;27:10-19.

17. Warren JW, Palumbo FB, Fitterman L, Speedie SM. Incidence and characteristics of antibiotic use in aged nursing home patients. J Am Geriatr Soc 1991; 39:963-972. 
18. Garazi M, Edwards B, Caccavale D, et al. Nursing homes as reservoirs of MRSA: Myth or reality? J Am Med Dir Assoc 2009;10:414-418.

19. Montgomery P, Semenchuk M, Nicolle LE. Antimicrobial use in nursing homes in Manitoba. J Geriatr Drug Ther 1995;9:55-74.

20. Yakabowich MR, Keeley G, Montgomery PR. Impact of a formulary on personal care homes in Manitoba. CMAJ 1994;150:1601-1607.

21. Loeb MB, Craven S, McGeer AJ, et al. Risk factors for resistance to antimicrobial agents among nursing home residents. Am J Epidemiol 2003;157:40-47.

22. Brugnaro P, Fedeli U, Pellizzer G, et al. Clustering and risk factors of methicillin-resistant Staphylococcus aureus carriage in two Italian long-term care facilities. Infection 2009;37:216-221.

23. Beck-Sague C, Villarino E, Giuliano D, et al. Infectious diseases and death among nursing home residents: Results of surveillance in 13 nursing homes. Infect Control Hosp Epidemiol 1994;15:494-496.

24. Pettersson E, Vernby A, Molstad S, Lundborg CS. Infections and antibiotic prescribing in Swedish nursing homes: A cross-sectional study. Scand J Infect Dis 2008;40:393-398.

25. Zimmer JG, Bentley DW, Valenti WM, Watson NM. Systemic antibiotic use in nursing homes. A quality assessment. J Am Geriatr Soc 1986;34:703-710.

26. Blix HS, Bergman J, Schjott J. How are antibacterials used in nursing homes? Results from a point-prevalence prescription study in 44 Norwegian nursing homes. Pharmacoepidemiol Drug Saf 2010;19:1025-1030.

27. McClean P, Hughes C, Tunney M, et al. Antimicrobial prescribing in European nursing homes. J Antimicrob Chemother 2011;66:1609-1616.

28. Moro ML, Mongardi M, Marchi M, Taroni F. Prevalence of long-term care acquired infections in nursing and residential homes in the Emilia-Romagna Region. Infection 2007;35:250-255.

29. Blix HS, Roed J, Sti MO. Large variation in antibacterial use among Norwegian nursing homes. Scand J Infect Dis 2007;39:536-541.

30. Jones SR, Parker DF, Liebow ES, et al. Appropriateness of antibiotic therapy in long-term care facilities. Am J Med 1987;83:499-502.

31. Katz PR, Beam TRJ, Brand F, Boyce K. Antibiotic use in the nursing home Physician practice patterns. Arch Intern Med 1990;150:1465-1468.

32. Lee YL, Thrupp LD, Friis RH, et al. Nosocomial infection and antibiotic utilization in geriatric patients: A pilot prospective surveillance program in skilled nursing facilities. Gerontology 1992;38:223-232.

33. Jacobson C, Strausbaugh LJ. Incidence and impact of infection in a nursing home care unit. Am J Infect Control 1990;18:151-159.

34. Warshaw G, Mehdizadeh S, Applebaum RA. Infections in nursing homes: Assessing quality of care. J Gerontol A Biol Sci Med Sci 2001;56:M120-M123.

35. Loeb M, McGeer A, Simor A, et al. Facility-level correlates of antimicrobial use in nursing homes. Infect Control Hosp Epidemiol 2004;25:173-176.

36. Mott PD, Barker WH. Treatment decisions for infections occurring in nursing home residents. J Am Geriatr Soc 1988;36:820-824.

37. Mylotte JM, Keagle J. Benchmarks for antibiotic use and cost in long-term care. J Am Geriatr Soc 2005;53:1117-1122.

38. ESAC. Report on point prevalence survey of antimicrobial presciption in European nursing homes, 2009. 2010. [report]

39. Latour K, Jans B, and the HALT management team. Healthcare associated infections in long-term care facilities; results of the pilot point prevalence survey. 2011. [report]

40. Loeb M, Bentley DW, Bradley S, et al. Development of minimum criteria for the initiation of antibiotics in residents of long-term-care facilities: Results of a consensus conference. Infect Control Hosp Epidemiol 2001;22: $120-124$.

41. Bradley SF. Issues in the management of resistant bacteria in long-term-care facilities. Infect Control Hosp Epidemiol 1999;20:362-366.

42. Raz R. The clinical impact of multiresistant gram-positive microorganisms in long-term care facilities. J Am Med Dir Assoc 2003;4:S100-S104.

43. McGeer A, Campbell B, Emori TG, et al. Definitions of infection for surveillance in long-term care facilities. Am J Infect Control 1991;19:1-7.

44. Brown NK, Thompson DJ. Nontreatment of fever in extended-care facilities. N Engl J Med 1979;300:1246-1250.

45. D'Agata E, Mitchell SL. Patterns of antimicrobial use among nursing home residents with advanced dementia. Arch Intern Med 2008;168:357-362.

46. Van Der Steen JT, Pasman HR, Ribbe MW, et al. Discomfort in dementia patients dying from pneumonia and its relief by antibiotics. Scand J Infect Dis 2009; $41: 143-151$

47. Van Der Steen JT. Prolonged life and increased symptoms vs prolonged dying and increased comfort after antibiotic treatment in patients with dementia and pneumonia. Arch Intern Med 2011;171:93-94.

48. Van Der Steen JT, Lane P, Kowall NW, et al. Antibiotics and mortality in patients with lower respiratory infection and advanced dementia. J Am Med Dir Assoc 2012;13:156-161.

49. Gleckman RA. Antibiotic concerns in the elderly. A clinician's perspective. Infect Dis Clin North Am 1995;9:575-590.

50. Crossley K, Peterson PK. Infections in the elderly-new developments. Curr Clin Top Infect Dis 1998;18:75-100.

51. Yoshikawa TT. Antimicrobial resistance and aging: Beginning of the end of the antibiotic era? J Am Geriatr Soc 2002;50:S226-S229.

52. Barr B, Wilcox MH, Brady A, et al. Prevalence of methicillin-resistant Staphylococcus aureus colonization among older residents of care homes in the United Kingdom. Infect Control Hosp Epidemiol 2007;28:853-859.
53. Bradley SF, Terpenning MS, Ramsey MA, et al. Methicillin-resistant Staphylococcus aureus: colonization and infection in a long-term care facility. Ann Intern Med 1991;115:417-422.

54. Bradley SF. Methicillin-resistant Staphylococcus aureus: long-term care concerns. Am J Med 1999;106:2S-10S.

55. Chang CM, Lauderdale TL, Lee HC, et al. Colonisation of fluoroquinoloneresistant Haemophilus influenzae among nursing home residents in southern Taiwan. J Hosp Infect 2010;75:304-308.

56. Cretnik TZ, Vovko P, Retelj M, et al. Prevalence and nosocomial spread of methicillin-resistant Staphylococcus aureus in a long-term-care facility in Slovenia. Infect Control Hosp Epidemiol 2005;26:184-190.

57. Crnich CJ, Safdar N, Robinson J, Zimmerman D. Longitudinal trends in antibiotic resistance in US nursing homes, 2000-2004. Infect Control Hosp Epidemiol 2007;28:1006-1008.

58. Crossley K. Long-term care facilities as sources of antibiotic-resistant nosocomial pathogens. Curr Opin Infect Dis 2001;14:455-459.

59. de Neeling AJ, van Leeuwen WJ, Schouls LM, et al. Resistance of staphylococci in The Netherlands: surveillance by an electronic network during 1989-1995. J Antimicrob Chemother 1998;41:93-101.

60. Donskey CJ, Ray AJ, Hoyen CK, et al. Colonization and infection with multiple nosocomial pathogens among patients colonized with vancomycin-resistant Enterococcus. Infect Control Hosp Epidemiol 2003;24:242-245

61. Drinka PJ. Long term tracking of methicillin-resistant Staphylococcus aureus in a large skilled nursing facility. J Am Geriatr Soc 2004;52:1968.

62. Eveillard M, Charru P, Rufat P, et al. Methicillin-resistant Staphylococcus aureus carriage in a long-term care facility: Hypothesis about selection and transmission. Age Ageing 2008;37:294-299.

63. Flamm RK, Weaver MK, Thornsberry C, et al. Factors associated with relative rates of antibiotic resistance in Pseudomonas aeruginosa isolates tested in clinical laboratories in the United States from 1999 to 2002. Antimicrob Agents Chemother 2004;48:2431-2436.

64. Flint JA, Ryan P, Gordon DL. Prevalence of MRSA in South Australian nursing homes. Med J Aust 1998;169:559-560.

65. Fraise AP, Mitchell K, O'Brien SJ, et al. Methicillin-resistant Staphylococcus aureus (MRSA) in nursing homes in a major UK city: An anonymized point prevalence survey. Epidemiol Infect 1997;118:1-5.

66. Frenay HM, Peerbooms PG, van Leeuwen WJ, et al. Nursing homes: not a source of methicillin-resistant Staphylococcus aureus in The Netherlands. Clin Infect Dis 1994;19:213-214

67. Greenland K, Rijnders M, Mulders M, et al. Low prevalence of methicillinresistant Staphylococcus aureus in Dutch nursing homes. J Am Geriatr Soc 2011;59:768-769.

68. Ho PL, Wang TKF, Ching P, et al. Epidemiology and genetic diversity of methicillin-resistant Staphylococcus aureus strains in residential care homes for elderly persons in Hong Kong. Infect Control Hosp Epidemiol 2007;28: 671-678.

69. Hoefnagels-Schuermans A, Niclaes L, Buntinx F, et al. Molecular epidemiology of methicillin-resistant Staphylococcus aureus in nursing homes: a crosssectional study. Infect Control Hosp Epidemiol 2002;23:546-549.

70. Karabay O, Otkun MT, Yavuz MT, Otkun M. Nasal carriage of methicillinresistant and methicillin-susceptible Staphylococcus aureus in nursing home residents in Bolu, Turkey. West Indian Med J 2006;55:183-187.

71. Kerttula AM, Lyytikainen O, Virolainen A, et al. Staphylococcus aureus colonization among nursing home residents in a large Finnish nursing home. Scand J Infect Dis 2007;39:996-1001.

72. Kreman T, Hu J, Pottinger J, Herwaldt LA. Survey of long-term-care facilities in Iowa for policies and practices regarding residents with methicillin-resistant Staphylococcus aureus or vancomycin-resistant enterococci. Infect Control Hosp Epidemiol 2005;26:811-815.

73. Larson E, Bobo L, Bennett R, et al. Lack of care giver hand contamination with endemic bacterial pathogens in a nursing home. Am J Infect Control 1992;20: $11-15$.

74. Lautenbach E, Marsicano R, Tolomeo P, et al. Epidemiology of antimicrobia resistance among gram-negative organisms recovered from patients in a multistate network of long-term care facilities. Infect Control Hosp Epidemiol 2009;30:790-793.

75. Lee YL, Cesario T, Gupta G, et al. Surveillance of colonization and infection with Staphylococcus aureus susceptible or resistant to methicillin in a community skilled-nursing facility. Am J Infect Control 1997;25:312-321.

76. Lee YL, Cesario T, Pax A, et al. Nasal colonization by Staphylococcus aureus in active, independent, community seniors. Age Ageing 1999;28:229-232.

77. Lee YL, Cesario T, Tran C, et al. Nasal colonization by methicillin-resistant coagulase-negative Staphylococcus in community skilled nursing facility patients. Am J Infect Control 2000;28:269-272.

78. Li F, Arnsberger P, Miller FD. Profile of methicillin-resistant Staphylococcus aureus among nursing home residents in Hawai'i. Hawaii Med J 2010;69: 126-129.

79. Maslow JN, Lautenbach E, Glaze T, et al. Colonization with extraintestinal pathogenic Escherichia coli among nursing home residents and its relationship to fluoroquinolone resistance. Antimicrob Agents Chemother 2004;48: 3618-3620.

80. Maslow JN, Lee B, Lautenbach E. Fluoroquinolone-resistant Escherichia col carriage in long-term care facility. Emerg Infect Dis 2005;11:889-894. 
81. Mody L, Kauffman CA, Donabedian S, et al. Epidemiology of Staphylococcus aureus colonization in nursing home residents. Clin Infect Dis 2008;46: 1368-1373.

82. Monaco M, Bombana E, Trezzi L, et al. Methicillin-resistant Staphylococcus aureus colonising residents and staff members in a nursing home in Northern Italy. J Hosp Infect 2009;73:182-184.

83. Mulhausen PL, Harrell LJ, Weinberger $\mathrm{M}$, et al. Contrasting methicillinresistant Staphylococcus aureus colonization in Veterans Affairs and community nursing homes. Am J Med 1996;100:24-31.

84. Nicolas-Chanoine MH, Jarlier V. Extended-spectrum beta-lactamases in longterm-care facilities. Clin Microbiol Infect 2008;14:111-116.

85. O'Fallon E, Pop-Vicas A, D'Agata E. The emerging threat of multidrug-resistant gram-negative organisms in long-term care facilities. J Gerontol A Biol Sci Med Sci 2009;64:138-141.

86. O'Fallon E, Schreiber R, Kandel R, D’Agata EMC. Multidrug-resistant gramnegative bacteria at a long-term care facility: Assessment of residents, healthcare workers, and inanimate surfaces. Infect Control Hosp Epidemiol 2009;30:1172-1179.

87. O'Fallon E, Kandel R, Schreiber R, D'Agata EMC. Acquisition of multidrugresistant gram-negative bacteria: Incidence and risk factors within a long-term care population. Infect Control Hosp Epidemiol 2010;31: 1148-1153.

88. O'Sullivan NR, Keane CT. The prevalence of methicillin-resistant Staphylococcus aureus among the residents of six nursing homes for the elderly. J Hosp Infect 2000;45:322-329.

89. Owen MK. Prevalence of oral methicillin-resistant Staphylococcus aureus in an institutionalized veterans population. Spec Care Dentist 1994;14:75-79.

90. Padiglione AA, Grabsch E, Wolfe R, et al. The prevalence of fecal colonization with VRE among residents of long-term-care facilities in Melbourne, Australia. Infect Control Hosp Epidemiol 2001;22:576-578.

91. Pop-Vicas A, Mitchell SL, Kandel R, et al. Multidrug-resistant gram-negative bacteria in a long-term care facility: Prevalence and risk factors. J Am Geriatr Soc 2008;56:1276-1280.

92. Rank EL. The emergence of methicillin resistant Staphylococcus aureus in extended care facilities in northern Connecticut between 1986 and 1990. Conn Med 1991;55:507-510.

93. Reynolds C, Quan V, Kim D, et al. Methicillin-resistant Staphylococcus aureus (MRSA) carriage in 10 nursing homes in Orange County, California. Infect Control Hosp Epidemiol 2011;32:91-93.

94. Rogers MAM, Mody L, Chenoweth C, et al. Incidence of antibiotic-resistant infection in long-term residents of skilled nursing facilities. Am J Infect Control 2008;36:472-475.

95. Rooney PJ, O'Leary MC, Loughrey AC, et al. Nursing homes as a reservoir of extended-spectrum beta-lactamase (ESBL)-producing ciprofloxacin-resistant Escherichia coli. J Antimicrob Chemother 2009;64:635-641.

96. Shlaes DM, Lehman MH, Currie-McCumber CA, et al. Prevalence of colonization with antibiotic resistant gram-negative bacilli in a nursing home care unit: The importance of cross-colonization as documented by plasmid analysis. Infect Control 1986;7:538-545.

97. Smith CS, Parnell P, Hodgson G, et al. Are methicillin-resistant Staphylococcus aureus that produce Panton-Valentine leucocidin (PVL) found among residents of care homes? J Antimicrob Chemother 2008;62:968-972.

98. Stone ND, Lewis DR, Lowery HK, et al. Importance of bacterial burden among methicillin-resistant Staphylococcus aureus carriers in a long-term care facility. Infect Control Hosp Epidemiol 2008;29:143-148.

99. Strausbaugh LJ, Jacobson C, Sewell DL, et al. Methicillin-resistant Staphylococcus aureus in extended-care facilities: Experiences in a Veterans' Affairs nursing home and a review of the literature. Infect Control Hosp Epidemiol $1991 ; 12: 36-45$.

100. Suetens C, Niclaes L, Jans B, et al. Determinants of methicillin-resistant Staphylococcus aureus carriage in nursing homes. Age Ageing 2007;36:327-330.

101. SWAB2009. Nethmap 2009-Consumption of antimicrobial agents and antimicrobial resistance among medically important bacteria in the Netherlands. 2009. [report]

102. Terpenning MS, Bradley SF, Wan JY, et al. Colonization and infection with antibiotic-resistant bacteria in a long-term care facility. J Am Geriatr Soc 1994:42:1062-1069.

103. Trick WE, Weinstein RA, DeMarais PL, et al. Colonization of skilled-care facility residents with antimicrobial-resistant pathogens. J Am Geriatr Soc 2001:49:270-276.

104. Viray M, Linkin D, Maslow JN, et al. Longitudinal trends in antimicrobial susceptibilities across long-term-care facilities: Emergence of fluoroquinolone resistance. Infect Control Hosp Epidemiol 2005;26:56-62.

105. von Baum H, Schmidt C, Svoboda D, et al. Risk factors for methicillin-resistant Staphylococcus aureus carriage in residents of German nursing homes. Infect Control Hosp Epidemiol 2002;23:511-515.

106. Vovko P, Retelj M, Cretnik TZ, et al. Risk factors for colonization with methicillin-resistant Staphylococcus aureus in a long-term-care facility in Slovenia. Infect Control Hosp Epidemiol 2005;26:191-195.

107. Vromen M, van der Ven AJ, Knols A, Stobberingh EE. Antimicrobial resistance patterns in urinary isolates from nursing home residents. Fifteen years of data reviewed. J Antimicrob Chemother 1999;44:113-116.

108. Ward TT, Strausbaugh LJ. Increasing prevalence of methicillin-resistant Staphylococus aureus in hospitals and nursing homes: The Oregon experience. Infections in Medicine 1992;9:46-51.
109. Zervos MJ, Terpenning MS, Schaberg DR, et al. High-level aminoglycosideresistant enterococci. Colonization of nursing home and acute care hospital patients. Arch Intern Med 1987;147:1591-1594.

110. Wendt C, Krause C, Xander LU, et al. Prevalence of colonization with vancomycin-resistant enterococci in various population groups in Berlin. Germany. J Hosp Infect 1999;42:193-200.

111. Hsu CC. Serial survey of methicillin-resistant Staphylococcus aureus nasal carriage among residents in a nursing home. Infect Control Hosp Epidemiol $1991 ; 12: 416-421$.

112. Troillet N, Carmeli Y, Samore MH, et al. Carriage of methicillin-resistant Staphylococcus aureus at hospital admission. Infect Control Hosp Epidemiol 1998; 19:181-185.

113. Strausbaugh LJ, Crossley KB, Nurse BA, Thrupp LD. Antimicrobial resistance in long-term-care facilities. Infect Control Hosp Epidemiol 1996;17:129-140.

114. Nicolle E, Sellers HE. Resistant bacteria in nursing homes: A rational approach. Hosp Pract (Minneap) 1996;31:11, 15.

115. Weinstein RA. Resistant bacteria and infection control in the nursing home and hospital. Bull N Y Acad Med 1987;63:337-344.

116. Lee YL, Gupta G, Cesario T, et al. Colonization by Staphylococcus aureus resistant to methicillin and ciprofloxacin during 20 months' surveillance in a private skilled nursing facility. Infect Control Hosp Epidemiol 1996;17: 649-653.

117. Lee YL, Cesario T, McCauley V, et al. Low-level colonization and infection with ciprofloxacin-resistant gram-negative bacilli in a skilled nursing facility. Am J Infect Control 1998;26:552-557.

118. Mendelson G, Yearmack Y, Granot E, et al. Staphylococcus aureus carrier state among elderly residents of a long-term care facility. J Am Med Dir Assoc 2003; 4:125-127.

119. Nurul Atifah MA, Loo HKC, Subramaniam G, et al. Faecal prevalence of extended-spectrum Beta-lactamase (ESBL)-producing coliforms in a geriatric population and among haematology patients. Malays J Pathol 2005;27:75-81.

120. O'Sullivan NP, Keane CT. Risk factors for colonization with methicillinresistant Staphylococcus aureus among nursing home residents. J Hosp Infect 2000;45:206-210.

121. Washio M, Nishisaka S, Kishikawa K, et al. Incidence of methicillin-resistant Staphylococcus aureus (MRSA) isolation in a skilled nursing home: A third report on the risk factors for the occurrence of MRSA infection in the elderly. J Epidemiol 1996;6:69-73.

122. Washio M. Risk factors for methicillin-resistant Staphylococcus aureus (MRSA) infection in a Japanese elderly care nursing home. Epidemiol Infect 1997;119: 285.

123. Benenson S, Cohen MJ, Block C, et al. Vancomycin-resistant enterococci in long-term care facilities. Infect Control Hosp Epidemiol 2009;30: 786-789.

124. Cohen AE, Lautenbach E, Morales KH, Linkin DR. Fluoroquinolone-resistant Escherichia coli in the long-term care setting. Am J Med 2006;119: 958-963.

125. Coll PP, Crabtree BF, O'Connor PJ, Klenzak S. Clinical risk factors for methicillin-resistant Staphylococcus aureus bacteriuria in a skilled-care nursing home. Arch Fam Med 1994;3:357-360.

126. Muder RR, Brennen C, Drenning SD, et al. Multiply antibiotic-resistant gramnegative bacilli in a long-term-care facility: A case-control study of patient risk factors and prior antibiotic use. Infect Control Hosp Epidemiol 1997;18: 809-813.

127. Sandoval C, Walter SD, McGeer A, et al. Nursing home residents and Enterobacteriaceae resistant to third-generation cephalosporins. Emerg Infect Dis 2004; 10:1050-1055.

128. Thomas JC, Bridge J, Waterman S, et al. Transmission and control of methicillin-resistant Staphylococcus aureus in a skilled nursing facility. Infect Control Hosp Epidemiol 1989;10:106-110.

129. Capitano B, Nicolau DP. Evolving epidemiology and cost of resistance to antimicrobial agents in long-term care facilities. J Am Med Dir Assoc 2003;4: S90-S99.

130. Coll PP, Nurse BA. Implications of methicillin-resistant Staphylococcus aureus on nursing home practice. J Am Board Fam Pract 1992;5:193-200.

131. Drinka P. Limiting the impact of antibiotic resistance in nursing homes. J Am Med Dir Assoc 2010;11:537-539.

132. Loeb M. Antibiotic use in long-term-care facilities: Many unanswered questions. Infect Control Hosp Epidemiol 2000;21:680-683.

133. Mao CA, Siegler EL, Abrutyn E. Antimicrobial resistance patterns in long term geriatric care. Implications for drug therapy. Drugs Aging 1996;8: 162-170.

134. Murphy S, Denman S, Bennett RG, et al. Methicillin-resistant Staphylococcus aureus colonization in a long-term-care facility. J Am Geriatr Soc 1992;40: 213-217.

135. Mody L, Maheshwari S, Galecki A, et al. Indwelling device use and antibiotic resistance in nursing homes: Identifying a high-risk group. J Am Geriatr Soc 2007;55:1921-1926.

136. Boyce JM. Methicillin-resistant Staphylococcus aureus in hospitals and longterm care facilities: Microbiology, epidemiology, and preventive measures. Infect Control Hosp Epidemiol 1992;13:725-737.

137. Bradley SF. Methicillin-resistant Staphylococcus aureus in nursing homes. Epidemiology, prevention and management. Drugs Aging 1997;10:185-198.

138. Farver D. Appropriate antibiotic use in long-term care facilities. S D J Med 1997;50:411-412. 
139. Raab U, Kahlau D, Wagenlehner F, et al. Prevalence of and risk factors for carriage of Panton-Valentine leukocidin-positive methicillin-resistant Staphylococcus aureus among residents and staff of a German nursing home. Infect Control Hosp Epidemiol 2006;27:208-211.

140. Wingard E, Shlaes JH, Mortimer EA, Shlaes DM. Colonization and crosscolonization of nursing home patients with trimethoprim-resistant gramnegative bacilli. Clin Infect Dis 1993;16:75-81.

141. Trick WE, Kuehnert MJ, Quirk SB, et al. Regional dissemination of vancomycin-resistant enterococci resulting from interfacility transfer of colonized patients. J Infect Dis 1999;180:391-396.

142. Cox RA, Bowie PE. Methicillin-resistant Staphylococcus aureus colonization in nursing home residents: A prevalence study in Northamptonshire. J Hosp Infect 1999;43:115-122.

143. Muder RR, Brennen C, Wagener MM, et al. Methicillin-resistant staphylococcal colonization and infection in a long-term care facility. Ann Intern Med 1991;114:107-112.

144. Bosso JA. Bacterial resistance to antibiotics: mechanisms and prevalence in hospitals and nursing homes. DICP 1989;23:556-561.

145. Croft AC, D'Antoni AV, Terzulli SL. Update on the antibacterial resistance crisis Med Sci Monit 2007;13:RA103-RA118.

146. Drinka P, Faulks JT, Gauerke C, et al. Adverse events associated with methicillin-resistant Staphylococcus aureus in a nursing home. Arch Intern Med 2001;161:2371-2377.

147. Suetens C, Niclaes L, Jans B, et al. Methicillin-resistant Staphylococcus aureus colonization is associated with higher mortality in nursing home residents with impaired cognitive status. J Am Geriatr Soc 2006;54: $1854-1860$.

148. Loeb M, Moss L, Stiller A, et al. Colonization with multiresistant bacteria and quality of life in residents of long-term-care facilities. Infect Control Hosp Epidemiol 2001;22:67-68.

149. Richards CLJ. Preventing antimicrobial-resistant bacterial infections among older adults in long-term care facilities. J Am Med Dir Assoc 2005;6: 144-151.

150. Smith PW, Rusnak PG. Infection prevention and control in the long-term-care facility. SHEA Long-Term-Care Committee and APIC Guidelines Committee. Am J Infect Control 1997;25:488-512.
151. Bentley DW, Cheney L. Infection control in the nursing home: The physician's role. Geriatrics 1990;45:59-66.

152. Norman DC. Management of antibiotic-resistant bacteria. J Am Geriatr Soc 2002;50:S242-S246.

153. Moro ML, Jans B, Cookson B, Fabry J. The burden of healthcare-associated infections in European long-term care facilities. Infect Control Hosp Epidemiol 2010;31:S59-S62.

154. Katz PR. Antibiotics for nursing home residents. When are they appropriate? Postgrad Med 1993;93:173-180.

155. Nicolle LE. Preventing infections in non-hospital settings: Long-term care. Emerg Infect Dis 2001;7:205-207.

156. American Medical Directors Association. Common infections in the Long Term Care Setting; clinical practice guideline. Columbia, MD, 2004 (Revised in 2011). 2004.

157. Smith PW, Bennett G, Bradley S, et al. SHEA/APIC Guideline: Infection prevention and control in the long-term care facility. Am J Infect Control 2008;36:504-535.

158. Hogberg LD, Heddini A, Cars O. The global need for effective antibiotics: Challenges and recent advances. Trends Pharmacol Sci 2010;31:509-515.

159. Dellit TH, Owens RC, McGowan JEJ, et al. Infectious Diseases Society of America and the Society for Healthcare Epidemiology of America guidelines for developing an institutional program to enhance antimicrobial stewardship. Clin Infect Dis 2007;44:159-177.

160. Mulligan T. Parenteral antibiotic therapy for patients in nursing homes. Rev Infect Dis 1991;13:S180-S183.

161. Zarocostas J. Urgent efforts needed globally to combat the spread of antimicrobial resistance, says WHO. BMJ 2011;342:d2205.

162. Goossens H. Antibiotic consumption and link to resistance. Clin Microbiol Infect 2009;15:12-15.

163. Achterberg WP, Went PB. Definition of urinary tract infection in nursing homes. J Hosp Infect 2012;80:99-100.

164. Stam-Bolink EM, Mithoe D, Baas WH, et al. Spread of a methicillin-resistant Staphylococcus aureus ST80 strain in the community of the northern Netherlands. Eur J Clin Microbiol Infect Dis 2007;26:723-727.

165. Sloane PD, Zimmerman S, Perez R, et al. Physician perspectives on medical care delivery in assisted living. J Am Geriatr Soc 2011;59:2326-2331. 